\title{
Enterobactin synthase polypeptides of Escherichia coli are present in an osmotic- shock-sensitive cytoplasmic locality
}

\author{
Feras M. Hantash, Marcus Ammerlaan† and Charles F. Earhart \\ Author for correspondence: Charles F. Earhart. Tel: +1512471 1561. Fax: +15124717088. \\ e-mail: earhart@mail.utexas.edu
}

Department of

Microbiology, The

University of Texas at

Austin, Austin TX 78712-

1095, USA

\begin{abstract}
The terminal reactions in the synthesis of the siderophore enterobactin (Ent) by Escherichia coli require the EntD, E, F and B/G polypeptides. The idea that these molecules form a complex (Ent synthase) that is membrane-associated was re-evaluated. In vitro results provided no evidence in support of the proposal: (i) Ent synthase activity occurred normally under conditions where membrane was either absent or disrupted by high concentrations of neutral detergents, and (ii) immunoprecipitation experiments conducted on extracts engaged in Ent synthesis failed to detect any association among the Ent polypeptides. However, Western blot analyses showed that EntE, F and B/G were released from cells by osmotic shock and freeze/thaw treatment but not by conversion of cells to spheroplasts. These results demonstrated that EntE, $F$ and B/G belong to the Beacham group $D$ class of proteins. The shockability of a given group D Ent protein was unaffected by the absence of either EntB/G or EntD and, for EntB/G, the N-terminus was sufficient for release by osmotic shock. The behaviour of group D proteins is generally attributed to their association (partial, loose or transient) with cytoplasmic membrane; therefore, the results are indirect evidence that Ent synthase interacts with membrane in vivo. At the very least, the data indicate that EntE, F and B/G are compartmentalized in $E$. coli and, because other biosynthetic enzymes for siderophores and surfactants are related to these Ent proteins, suggest that this entire protein class may be sequestered in vivo.
\end{abstract}

Keywords: enterobactin synthase, iron, osmotic shock, siderophore, Escherichia coli

\section{INTRODUCTION}

Iron is an essential element for Escherichia coli, as it is for almost all organisms. Like many bacteria and fungi, $E$. coli responds to iron-deficient environments by synthesizing and secreting a small compound with high affinity for $\mathrm{Fe}(\mathrm{III})$. Such iron-scavenging molecules are termed siderophores; uptake and intracellular dissociation of $\mathrm{Fe}$ (III)-siderophore complexes provides the necessary iron. The siderophore produced by all $E$. coli strains is enterobactin (Ent), a $670 \mathrm{Da}$ cyclic trimer of dihydroxybenzoylserine (DBS) (Neilands, 1981a). That

Present address: Department of Biology, University of Michigan, Ann Arbor, MI 48103-1048, USA.

Abbreviations: ACP, acyl carrier protein; DBS, dihydroxybenzoylserine; DHBA, dihydroxybenzoic acid; TCA, trichloroacetic acid. the task faced by the Ent system is formidable is evident from estimates that a rapidly growing $E$. coli cell must assimilate $10^{6} \mathrm{Fe}$ ions per division cycle (Braun, 1985; Earhart, 1987).

Six proteins are required for Ent biosynthesis. The first three steps, in which chorismate is converted to dihydroxybenzoic acid (DHBA) by the EntC, B/G and A proteins, are well characterized (Walsh et al., 1990). In contrast, the latter steps, in which the EntD, E, F and B/G polypeptides convert DHBA and Ser to Ent, are not clearly understood. DNA sequence homologies (Guilvout et al., 1993; Turgay et al., 1992) and enzymological data (Walsh et al., 1990) indicate that, as originally proposed by Bryce \& Brot (1972), the terminal reactions in Ent synthesis are similar to those for peptide antibiotics. That is, the three amide bonds of Ent are made non-ribosomally, presumably by the protein 
thiotemplate mechanism (Kleinkauf \& von Dohren, 1990; Marahiel, 1992). EntE (homodimer of $59 \mathrm{kDa}$ subunits) and EntF $(142 \mathrm{kDa})$ are both activating enzymes; EntE forms the DHBA-acyladenylate (Rusnak et al., 1989) and EntF activates and binds Ser to itself probably via a 4'-phosphopantetheine cofactor (Reichert et al., 1992; Rusnak et al., 1991). According to current models (Ammerlaan, 1994; Walsh et al., 1990), Ent synthesis continues with formation, on EntF, of DBS by a transamidation reaction between activated DHBA and Ser, and is completed when three DBS molecules are linked by transesterification. EntB/G and EntD are essential but their roles have not been determined. Ent $\mathrm{B} / \mathrm{G}(32.5 \mathrm{kDa})$ seems to be a bifunctional protein (Staab \& Earhart, 1990) required both for an early step in Ent biosynthesis (EntB activity; Rusnak et al., 1990) and an unidentified later step (EntG activity)(Greenwood \& Luke, 1976, 1980; Woodrow et al., 1975); the early and late synthetic activities of Ent $B / G$ are separable by mutation and appear to reside in the $\mathrm{N}$ - and C-termini of the protein, respectively. That EntB and EntG activities are on the same polypeptide is supported by the detection (unpublished results) of homology between the C-terminus of $\mathrm{EntB} / \mathrm{G}$ and the $\mathrm{N}$-terminus of iron-regulated HMWP2 of Yersinia enterocolitica (Guilvout et al., 1993); the homologous regions include a consensus substrate amino acid binding site for enzymes engaged in non-ribosomal peptide synthesis (Schlumbohm et al., 1991). EntD (23 kDa) is reported to be an integral cytoplasmic membrane protein (Armstrong et al., 1989); its gene shows homologies to two genes (sfp and gsp) of Bacillus spp. that are thought to be necessary for peptide antibiotic secretion (Borchert et al., 1994; Grossman et al., 1993).

The EntD, E, F and B/G proteins are believed to form a multi-enzyme complex (Ent synthase) that carries out the reaction $3 \mathrm{Ser}+3 \mathrm{DHBA}+6 \mathrm{ATP} \rightarrow \mathrm{Ent}+6 \mathrm{AMP}$ $+\mathrm{PP}_{\mathrm{i}}$ (Crosa, 1989; Silver \& Walderhaug, 1992). The idea that this complex exists was first suggested by Greenwood \& Luke (1976, 1980), who further postulated it was associated with the cytoplasmic membrane. Direct evidence for association among EntD, F and B/G consists of gel filtration and DEAE Sephadex chromatographic data, which demonstrated that under certain conditions some co-elution occurs (Greenwood \& Luke, 1976; Woodrow et al., 1979). Specifically, in decreasing order of stability, the complexes detected were EntDFG, EntDF and EntDG. Membrane-association of the complex, postulated to be through EntD (Greenwood \& Luke, 1976; Woodrow et al., 1979), would provide an efficient means to couple Ent synthesis and secretion. This idea gained support from the observation that EntD can be detected on the cytoplasmic face of the cytoplasmic membrane (Armstrong et al., 1989). On the other hand, (i) EntE has never been reported as part of a complex, (ii) EntE, F and B/G have been purified when overexpressed (Reichert et al., 1992; Rusnak et al., 1989, 1990), and partially purified when present in normal derepressed quantities (Bryce \& Brot, 1972; Greenwood \& Luke, 1976) by standard procedures for soluble proteins, (iii) the chromatographic conditions under which Ent protein complexes were detected (slow flow rate and low Sephadex exclusion limit) are those which favour non-specific interactions among proteins and (iv) localization artefacts resulting from overexpression of Ent biosynthetic proteins have been reported (Elkins \& Earhart, 1988) and may account for the association of EntD with cytoplasmic membrane.

Therefore, two commonly held ideas regarding the latter steps of Ent biosynthesis, i.e. that a complex of enzymes is responsible and that the complex is associated with the cytoplasmic membrane, have not been rigorously established. This work was undertaken to re-examine the localization and association of the Ent synthase proteins. In vitro work provided no evidence for the existence of a stable membrane-bound complex. However, studies with intact cells indicate that much of each of the EntE, $F$ and B/G proteins must be present in an unusual cellular domain. These proteins could be released from cells by osmotic shock but not by converting cells to spheroplasts. EntE, F and B/G can therefore be placed among the group $\mathrm{D}$ proteins (Beacham, 1979), along with such members as EFTu, thioredoxin (Lunn \& Pigiet, 1982) and DnaK (El Yaagoubi et al., 1994).

\section{METHODS}

Bacterial strains and plasmids. The bacterial strains and plasmids employed are described in Table 1. pAUT119Af was constructed by standard techniques (Sambrook et al., 1989) from previously described plasmids (Coderre \& Earhart, 1984; Studier et al., 1990); it directs the synthesis of a hybrid protein encoded by the first 12 codons of T $7 \mathrm{gp} 10$ fused inframe to the C-terminal 186 codons of entD. This plasmid complements entD mutations in vivo and in vitro but the predicted fusion protein has not been detected (Ammerlaan, 1994).

Growth of bacteria. M9 and LB-dipyridyl media were described by Miller (1972) and Chenault \& Earhart (1991), respectively; Chelex 100 resin (Bio-Rad) was used to prepare iron-depleted M9 medium as before (McIntosh \& Earhart, 1977). TMM medium, deficient in iron and phosphorus (Nossal \& Heppel, 1968), consists, per l, of Tris $(12 \cdot 11 \mathrm{~g})$, $\mathrm{NaCl}(4 \cdot 68 \mathrm{~g}), \mathrm{KCl}(2 \cdot 24 \mathrm{~g}), \mathrm{NaH}_{2} \mathrm{PO}_{4}(60 \mathrm{mg}), \mathrm{NH}_{4} \mathrm{Cl}$ $(1.07 \mathrm{~g}), \mathrm{ZnCl}_{2}(0.27 \mathrm{mg}), \mathrm{Na}_{2} \mathrm{SO}_{4}(40 \mathrm{mg}), \mathrm{MgSO}_{4} .7 \mathrm{H}_{2} \mathrm{O}$ $\left(247 \mathrm{mg}\right.$ ) and $\mathrm{CaCl}_{2}(22 \mathrm{mg}$ ) to $\mathrm{pH} 7.4$ with $\mathrm{HCl}$. Glucose (to $0.2 \%$ ) was added to TMM, otherwise the concentrations of glucose and supplements to M9 and TMM were as described (Pierce \& Earhart, 1986).

Osmotic shock. The osmotic shock procedure was that of LaVallie et al. (1993). The plasmolysing solution (SET) consisted of $20 \%(\mathrm{w} / \mathrm{v})$ sucrose, $2.5 \mathrm{mM}$ EDTA. $\mathrm{Na}_{2}$ and $20 \mathrm{mM}$ Tris/ $\mathrm{HCl}, \mathrm{pH} 8 \cdot 0$. Depending on the experiment, the shocking solution $\left(4^{\circ} \mathrm{C}\right)$ was deionized water, $2.5 \mathrm{mM}$ EDTA. $\mathrm{Na}_{2}$ and $20 \mathrm{mM}$ Tris/ $\mathrm{HCl}, \mathrm{pH} 8.0$ (ET), or cation solutions $\left(\mathrm{CaCl}_{2}\right.$ or $\left.\mathrm{MgCl}_{2}\right)$ at $50,100,200$ or $500 \mu \mathrm{M}$. Proteins in the shockate fraction were pelleted by addition of an equal volume of cold $10 \%$ trichloroacetic acid (TCA). Total (unfractionated) cells, shockate proteins and shocked cells were resuspended in equal volumes so that fractions from equal numbers of cells could be directly compared. Cells were 
Table 1. Bacterial strains and plasmids

\begin{tabular}{|c|c|c|}
\hline Strain/plasmid & Genotype/relevant characteristics & Reference/source \\
\hline \multicolumn{3}{|l|}{ Strains } \\
\hline W3110 & $\mathrm{F}^{-}$thyA36 deoC2 IN (rrnD-rrnE) & $\begin{array}{l}\text { J. R. Walker, The University of Texas at } \\
\text { Austin }\end{array}$ \\
\hline AB1515 & $\begin{array}{l}\mathrm{F}^{-} \text {thi-1 trpE38 purE42 proC14 leu-6 lacY1 mtl-1 } \\
\text { xyl-5 rpsL109 azi-6 fhuA23 tsx-67 supE44 }\end{array}$ & Langman et al. (1972) \\
\hline AB1515.24 & ent $B:: \operatorname{Tn} 5$ ent $\mathrm{G}$ derivative of $\mathrm{AB} 1515\left(\mathrm{EntB}^{-} \mathrm{G}^{-}\right)$ & Staab \& Earhart (1990) \\
\hline AB1515.43 & ent $B:: \operatorname{Tn} 5$ ent $G$ derivative of $A B 1515\left(\mathrm{EntB}^{+} \mathrm{G}^{-}\right)$ & Staab \& Earhart $(1990)$ \\
\hline AB1515.5-4 & ent $D:: \operatorname{Tn} 5$ derivative of $\mathrm{AB} 1515$ & Ammerlaan (1994) \\
\hline AN93 & entE 405 purE $E^{+}$derivative of $\mathrm{AB} 1515$ & $\begin{array}{l}\text { I. G. Young, Australian National University, } \\
\text { Canberra }\end{array}$ \\
\hline AN117 & entF purE $E^{+}$derivative of $\mathrm{AB} 1515$ & I. G. Young \\
\hline AN102 & fepC $p u r E^{+}$transductant of $\mathrm{AB} 1515$ & Cox et al. (1970); Chenault \& Earhart (1991) \\
\hline 1D2 & fes derivative of $\mathrm{AB} 1515$ & Pierce et al. (1983) \\
\hline \multicolumn{3}{|l|}{ Plasmids } \\
\hline pPC12 & pBR322 carrying $4.0 \mathrm{~kb} E c o$ RI fragment, ent $D^{+}$ & Coderre \& Earhart (1984) \\
\hline pGEM3Z & $\begin{array}{l}\mathrm{Ap}^{\mathrm{r}}, \mathrm{T} 7 \text { promoter, pUC19 multicloning site, lacZ } \alpha \\
\text { peptide, SP6 promoter }\end{array}$ & Promega \\
\hline pET-11a & $\begin{array}{l}\mathrm{Ap}^{\mathrm{r}}, \mathrm{T} 7 \text { promoter, } l a c \text { promoter, } \mathrm{T} 7 \mathrm{gp} 10 \mathrm{RBS} \text { and } \\
\text { first } 12 \text { codons, Bam } \mathrm{HI} \text { cloning site, } \mathrm{T} 7 \text { terminator }\end{array}$ & Studier et al. (1990) \\
\hline pAUT100r & $\begin{array}{l}\text { ent } D^{+}, 3 \cdot 1 \mathrm{~kb} \text { Bam } \mathrm{HI} \text { fragment of pPC12 into } \\
\text { Bam HI site of pGEM } 3 \mathrm{Z}\end{array}$ & This study \\
\hline pAUT102 & $\begin{array}{l}\text { ent } D^{+}, 1.0 \mathrm{~kb} \text { Stul-BamHI fragment of pAUT100r } \\
\text { into SmaI/Bam HI-digested pGEM } 3 Z\end{array}$ & This study \\
\hline pAUT119Af & $\begin{array}{l}\text { ent } D^{+}, \text {T7gp10-EntD fusion protein, } 0.9 \mathrm{~kb} \mathrm{TaqI} \\
\text { fragment (filled) of pAUT102 into filled Bam HI site } \\
\text { of pET-11a }\end{array}$ & This study \\
\hline
\end{tabular}

resuspended in water and TCA-precipitable material was resuspended in $0.3 \mathrm{M} \mathrm{KOH}$.

Freeze/thaw. Cells were resuspended in ET to $\mathrm{OD}_{420}=5$ (Bausch \& Lomb Spectronic 20) and frozen immediately in a dry-ice/ethanol bath for $15 \mathrm{~min}$. Cells were allowed to thaw at room temperature and then harvested by centrifugation $\left(4^{\circ} \mathrm{C}\right)$. The supernatant was made $5 \%$ TCA. Thawed cells and TCAprecipitable material were resuspended in equal volumes as described above.

Spheroplasting. Cells were converted to spheroplasts by the method of Kaback (1971). Cells were resuspended in $20 \%$ (w/v) sucrose, $30 \mathrm{mM}$ Tris/ $\mathrm{HCl}, \mathrm{pH} 8.0$ solution. Lysozyme and EDTA were added with gentle stirring to final concentrations of $0.7 \mathrm{mg} \mathrm{ml}^{-1}$ and $10 \mathrm{mM}$, respectively, and the stirring of the suspension was continued for $30 \mathrm{~min}$ at room temperature. Spheroplasts were harvested by centrifugation, the supernatant was made $5 \% \mathrm{TCA}$, and spheroplasts and supernatant proteins were resuspended as described above.

Electrophoresis of proteins and Western blot analysis. Samples were mixed with an equal volume of loading buffer $(10 \%$ glycerol, $0.125 \mathrm{M}$ Tris $/ \mathrm{HCl}, 1 \% \beta$-mercaptoethanol, $4.6 \%$ SDS, and $1 \mathrm{mg}$ bromophenol blue $\mathrm{ml}^{-1}$ ), boiled for 5 min and analysed on 11 or $15 \%$ polyacrylamide gels (Lugtenberg et al., 1975). Pre-stained protein molecular mass standards (high-range; Gibco-BRL), were used and where appropriate gels were stained with Coomassie Brilliant Blue $\mathrm{G}$. Western blot analyses were performed as described by Staab \& Earhart (1990). Antisera against EntB, E and F were prepared as described by Ammerlaan (1994) and Staab \& Earhart (1990), anti-PhoA antiserum was purchased from 5
Prime $\rightarrow 3$ Prime Inc.; anti-T7gp10 antiserum was from Novagen, and anti-acyl carrier protein antiserum was provided by C. Rock, St Jude Children's Research Hospital, respectively. Horseradish-peroxidase-conjugated goat antirabbit IgG (Bio-Rad) served as secondary antibody.

Ent synthase assays. Extracts were prepared from overnight cultures and from shockate fractions, which were obtained from mid-exponential phase $\left(\mathrm{OD}_{420}=0.5\right)$ cultures. Overnight cultures were harvested, resuspended in CS buffer (10 mM Tris/HCl, $\mathrm{pH} 8,5 \mathrm{mM}$ DTT) and passed through a French pressure cell at $18000-20000$ p.s.i. $(124 \cdot 2-138 \mathrm{MPa})$ three times. Cell debris was subsequently removed by centrifuging for $20 \mathrm{~min}$ at $20000 \mathrm{~g}$ (Greenwood \& Luke, 1976). Shockate fractions were concentrated in an Amicon unit using membranes with a molecular mass cut-off of $10 \mathrm{kDa}$. The Ent synthase assay was performed as described by Greenwood \& Luke (1976). In initial experiments (Table 2), extracts were prepared from cells grown in LB-dipyridyl medium and each sample was assayed in quadruplicate. The four values of a given sample were always within $10 \%$ of the mean. Also, specific activities varied directly with the degree of iron starvation [as monitored by the Arnow (1937) assay], and iron starvation was more consistently achieved when cells were grown in iron-deficient minimal media. Therefore, subsequent experiments were carried out with extracts from cultures grown in de-ferrated M9 or TMM medium and samples were assayed in duplicate. Representative values are shown.

Radioimmune precipitations. AB1515.5-4/pAUT119Af cells were grown at $37^{\circ} \mathrm{C}$ in de-ferrated $\mathrm{M} 9$ medium containing ampicillin $\left(200 \mu \mathrm{g} \mathrm{ml}^{-1}\right)$, kanamycin $\left(30 \mu \mathrm{g} \mathrm{m}^{-1}\right), 1 \mathrm{mM}$ 
Table 2. Ent synthase activities of wild-type and mutant $E$. coli strains

\begin{tabular}{|lccc|}
\hline Source of extract & Relevant genotype & $\begin{array}{c}\text { Reaction } \\
\text { conditions }\end{array}$ & $\begin{array}{c}\text { Serine incorporated } \\
\text { [nmol (mg protein) })^{-1} \text { ] }\end{array}$ \\
\hline None & NA & No protein & $0 \cdot 5$ \\
AN102 & ent $^{+} f e p C$ & No ATP & $2 \cdot 1$ \\
AN102 & ent $^{+} f e p C$ & No DHBA & $2 \cdot 1$ \\
AN102 & ent $^{+} f e p C$ & Complete & $17 \cdot 1$ \\
AN102 high* & ent $^{+} f e p C$ & Complete & $20 \cdot 8$ \\
1D2 & ent ${ }^{+} f e s$ & Complete & $10 \cdot 8$ \\
AB1515 & ent & $12 \cdot 2$ \\
AB1515.5-4 & entD::Tn5 & Complete & $2 \cdot 1$ \\
AB1515.5-4/ & entD/entD & Complete & $9 \cdot 6$ \\
pAUT119Af & & Complete & \\
AN93 & entE & Complete & $2 \cdot 1$ \\
AN117 & entF & Complete & $1 \cdot 4$ \\
AB1515.43 & ent $(G):: \operatorname{Tn} 5$ & Complete & $2 \cdot 0$ \\
\hline
\end{tabular}

*Extract subjected to an additional centrifugation $(2 \mathrm{~h}, 160000 \mathrm{~g})$ to remove membrane.

IPTG, and either $20 \mu \mathrm{M} \mathrm{FeCl}_{3}$ (high iron) or $1 \mu \mathrm{M} \mathrm{FeCl}_{3}$ (low iron) to $\mathrm{OD}_{420} 0 \cdot 8$. Radiolabel (EXPRE ${ }^{35} \mathrm{~S}^{35} \mathrm{~S}$, DuPont/NEN) was added $\left(1 \cdot 3 \mathrm{mCi}^{-1} ; 48 \cdot 1 \mathrm{MBq}^{-1}\right)$ for $10 \mathrm{~min}$, the cultures harvested and extracts prepared as for an Ent synthase assay. Extracts containing Ent synthase substrates were incubated at $37^{\circ} \mathrm{C}$ for $5 \mathrm{~min}$, at which point $20 \mu \mathrm{l}$ antiserum was added. Binding was allowed to proceed for $1 \mathrm{~h}$ during which the samples were gently rocked at $4{ }^{\circ} \mathrm{C}$. Antibody-bound proteins were then precipitated by addition of $20 \mu$ l Protein ASepharose beads (Pharmacia). After two washes with CS buffer containing $2 \%$ Tween 20 , bound proteins were released and solubilized with $1 \times$ sample loading buffer and analysed by SDS-PAGE $(15 \%)$. Labelled proteins were detected by autoradiography on Kodak XRP-1 film.

Phenolate assay. The method of Arnow (1937) was used to quantify the phenolate content of culture supernatants. Dihydroxybenzoic acid served as the standard.

Protein assay. Protein concentrations were determined by the Bradford (1976) assay using BSA as the standard.

\section{RESULTS}

\section{In vitro Ent synthase activity}

Evidence that Ent synthase exists as a membraneassociated multienzyme complex was sought from assays of the enzyme under a variety of conditions. Production of Ent synthase is repressed by growth in iron-replete media so all extracts were prepared from iron-starved cells. Strain AN102 (Chenault \& Earhart, 1991; Cox et al., 1970) was used as the source of normal enzyme; because it is defective in a cytoplasmic membrane protein (FepC) necessary for Ent-mediated iron uptake it is unusually sensitive to iron starvation, which makes it a good source of Ent (Neilands, 1981b) and Ent synthase. Results presented in Table 2 verify that EntD, $\mathrm{E}, \mathrm{F}$ and $\mathrm{B} / \mathrm{G}$ are all required for in vitro activity. The same low specific activities for these mutants were found when ATP was omitted from the reaction mixtures. The data also show that the entD mutation of AB1515.5-4 can be complemented in vitro by a putative hybrid EntD protein (T7gp10-EntD) encoded by plasmid pAUT119Af. The presence of ferriEnt esterase, the fes gene product, had as anticipated, no effect on Ent synthase assays, as shown by the specific activities of extracts of $\mathrm{AB} 1515$ and its fes derivative 1D2. (The assay measures the conversion of $\left[{ }^{14} \mathrm{C}\right] \mathrm{Ser}$ into forms soluble in ethyl acetate; the degradation products resulting from esterase cleavage of Ent and FeEnt are still soluble in ethyl acetate.) Other experiments (not shown) demonstrated that addition of polyclonal antibodies specific for EntE, EntF or EntB/G all reduced Ent synthase activity in AB1515.5-4/pAUT119Af extracts. Antibodies directed against the T7gp10 epitope of the hybrid EntD did not reduce Ent synthase activity in these extracts, an unexpected result particularly if EntD is part of a multienzyme complex.

Two observations bear on the in vivo complexity of Ent synthase. (i) Extracts prepared by sonication rather than by passage through a French pressure cell exhibited highly variable but generally very low activity. The significance of this unusual effect of the manner of lysis is unclear. (ii) Extracts subjected to high-speed centrifugation $(2 \mathrm{~h}, 160000 \mathrm{~g})$, a procedure which should pellet membranes and their associated proteins, had a higher rather than reduced specific activity compared to normal crude extracts (Table 2, AN102 high). Solubilized membrane pellets were inactive. Examination of the reaction products by TLC and HPLC showed that both 'high-speed' and regular extracts formed the same products (some Ent, primarily DBS) (Ammerlaan, 1994). These data suggest the Ent proteins are cytosolic.

Experiments were performed to test the effects on Ent synthase activity of agents influencing membrane and protein complex stability. As shown in Fig. 1, ionic detergents drastically reduced enzymic function; the $K_{\mathrm{i}}$ values for SDS and Sarkosyl are 0.025 and $0.05 \%$, 


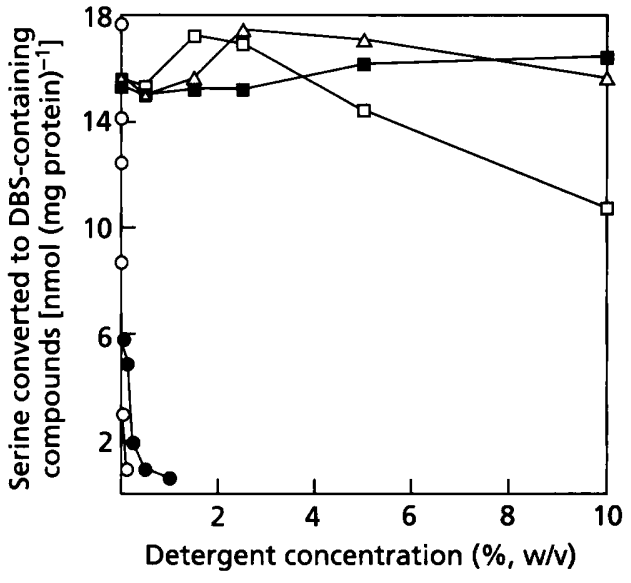

Fig. 1. Effect of detergents on Ent synthase activity. Extracts were prepared from AN102 grown at $37^{\circ} \mathrm{C}$ in iron-depleted M9

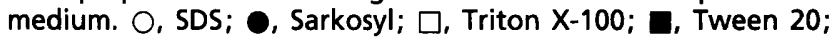
$\triangle, N P-40$

respectively. Likewise, $\mathrm{NaCl}$ was also inhibitory $\left(K_{\mathrm{i}}=\right.$ $150 \mathrm{mM}$; data not shown). Remarkably, however, addition of non-ionic detergents Triton X-100, Tween 20 , and NP-40 to the reaction mixtures at concentrations up to $10 \%$ had little effect. In vitro Ent synthase resistance to inhibitory effects of non-ionic detergents argues strongly against a mandatory need for membrane and also suggests that Ent synthase does not exist as a stable complex.

\section{Radioimmune precipitations of Ent synthase polypeptides}

Immune precipitations were performed to test for association among the EntD, E, F and $\mathrm{B} / \mathrm{G}$ proteins. Preliminary experiments (Ammerlaan, 1994) determined that the antisera had good specificity; in Western blots, anti-EntE serum immunoprecipitated only EntE and a non-iron-regulated $65 \mathrm{kDa}$ polypeptide, anti-EntF serum precipitated EntF and a non-iron-regulated $52 \mathrm{kDa}$ protein, and anti-EntB/G antibodies recognized, in addition to $\mathrm{EntB} / \mathrm{G}$, two non-iron-regulated proteins of 68 and $72 \mathrm{kDa}$. Polyclonal antiserum against the first 12 amino acids of T7gp10, present at the $\mathrm{N}$-terminus of the hybrid EntD protein, failed to detect EntD. The insensitivity of the Ent synthase reaction to detergent permitted the precipitation to be carried out as Ent synthesis was ongoing, in this case in the presence of $2 \%$ Tween 20. As shown in Fig. 2, even under the nonstringent conditions used only one iron-regulated protein of Ent synthase, the cognate protein of the antibody added, was immunoprecipitated. Similar results were obtained when Tween 20 was omitted (Ammerlaan, 1994). In lane 3, a protein with the migration properties of EntB (lane 7) was apparently precipitated along with EntE. However, the appearance of this protein was not reproducible and it was not detected under other even

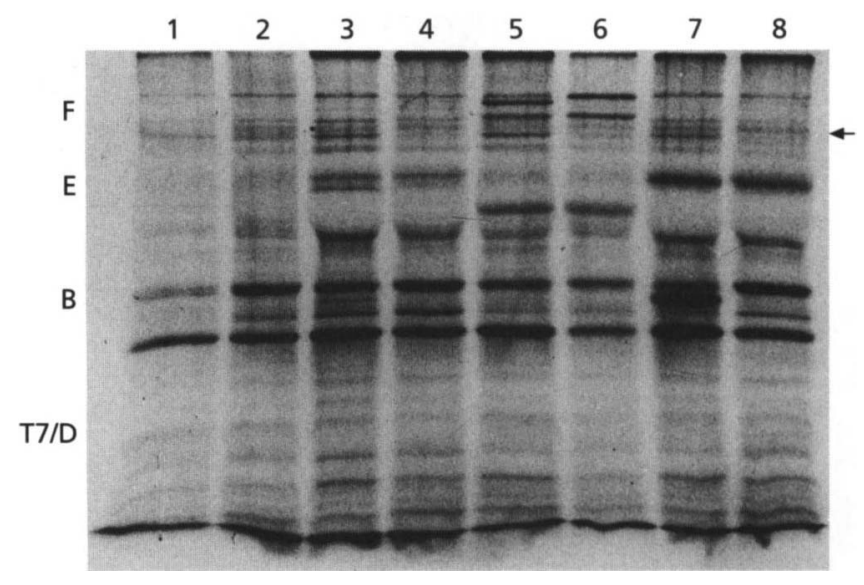

Fig. 2. Radioimmune precipitations against Ent-synthesizing extracts. Immune precipitations were carried out against radiolabelled AB1515.5-4/pAUT119Af extracts from cells grown under low (odd-numbered lanes) and high (even-numbered lanes) -iron conditions. Extracts were set up as Ent synthase reactions with $2 \%$ Tween 20 . Precipitations were carried out using antibodies directed against T7gp10 (lanes 1 and 2), EntE (lanes 3 and 4), EntF (lanes 5 and 6) and EntB/G (lanes 7 and 8). The expected migration of Ent proteins is indicated along the left edge of the gel. The arrow indicates an uncharacterized iron-regulated protein of $85-90 \mathrm{kDa}$.

less stringent conditions, such as in the absence of Tween 20. In addition, apparently the same ironregulated $85-90 \mathrm{kDa}$ polypeptide was present in lanes 3 , 5 and 7 ; the significance of this observation is unknown. Nothing can be concluded regarding EntD; our laboratory has been unable to observe EntD by a variety of expression systems (Coderre \& Earhart, 1989), Western blots, or radioimmune precipitation (Ammerlaan, 1994).

\section{Release of EntB/G, E and F by osmotic shock}

Periplasmic proteins are released from cells during the formation of spheroplasts and by osmotic shock; only the latter procedure also results in the release of several non-periplasmic enzymes, termed group $\mathrm{D}$ proteins (Beacham, 1979). Results shown in Fig. 3 demonstrate that EntE, $F$ and $B / G$ belong to the group $D$ protein class. Each of these proteins is found in the shockate (lane 2); EntE and EntB/G are present almost exclusively in this fraction whereas EntF, although obviously present in the shockate, remains primarily with the shocked cells. Importantly, the Ent proteins are not released by spheroplasting, unlike the control periplasmic protein alkaline phosphatase (PhoA). FepB, the periplasmic binding protein for ferrienterobactin, behaved like PhoA (data not shown). The appearance of Ent synthase proteins in the shockates was not the result of cell breakage, as can be seen from the results with acyl carrier protein $(\mathrm{ACP})$, a small $(8.86 \mathrm{kDa})$ cytoplasmic polypeptide. Other cytoplasmic proteins tested were DnaA $(50 \mathrm{kDa})$ and the $\tau$ and $\gamma$ subunits of DNA polymerase III ( 75 and $55 \mathrm{kDa}$, respectively) of $E$. coli 


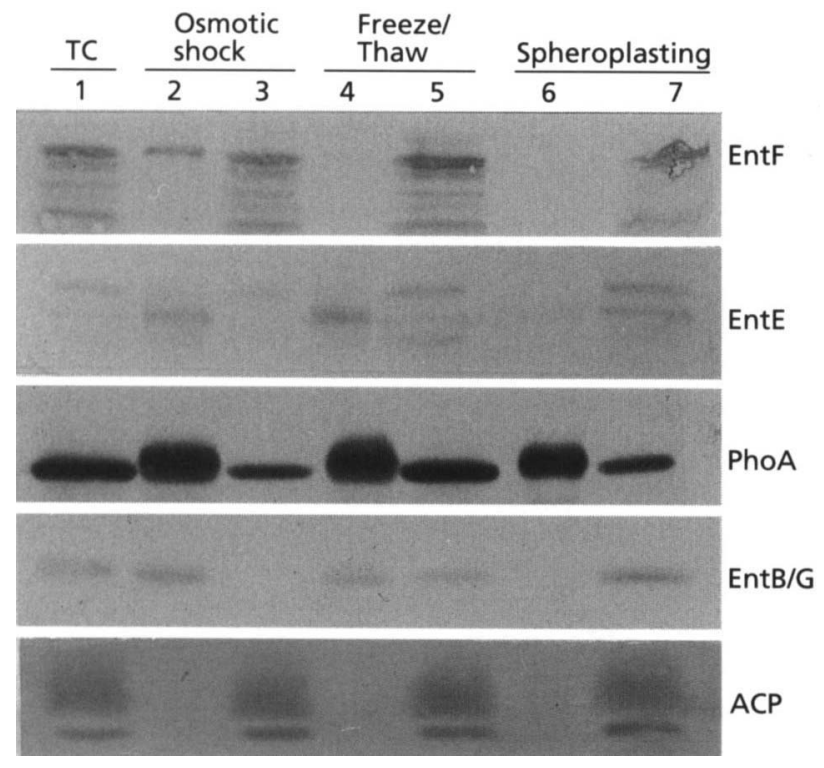

Fig. 3. EntB/G, EntE and EntF are group D proteins. Osmotic shock, freeze/thaw and spheroplasting were performed on $A B 1515$ cells grown to mid-exponential phase $\left(O D_{420} 0.5\right)$ in TMM. Fractions from equal numbers of cells were analysed by Western blots after electrophoresis on $11 \%$ polyacrylamide gels. Only relevant portions of blots are shown. Lanes: 1, TC (total cells); 2, shockate; 3, shocked cells; 4, supernatant after freeze/thaw; 5 , cells after freeze/thaw; 6 , supernatant after spheroplasting; 7, spheroplasts. PhoA and ACP served as controls for periplasmic and cytoplasmic proteins, respectively. Molecular masses (kDa) of the polypeptides are: EntF, 142; EntE, 59; PhoA, 43; EntB/G, 32.5; ACP, 8.86 but migrates as 20 (C. Rock, personal communication).

AB1515 and, from E. coli W3110 grown in M9/lactose medium, $\beta$-galactosidase $(116 \mathrm{kDa})$; all were found in shocked cells and not the shockates (data not shown). The localization characteristics of the Ent synthase proteins were neither strain-specific nor medium-dependent, as similar results were obtained with $E$. coli W3110 as well as with AB1515 and in M9 as well as in TMM medium.

Group D and periplasmic proteins are also released by freeze/thaw treatment, although not as effectively as by osmotic shock (Lunn \& Pigiet, 1982). EntE and B/G are released by freeze/thaw but only trace amounts of EntF were detected in the soluble fraction (Fig. 3, lanes 4 and $5)$.

\section{Divalent cations suppress release of Ent synthase proteins}

Release of group D proteins thioredoxin (Lunn \& Pigiet, 1982) and DnaK (El Yaagoubi et al., 1994) is blocked by addition of divalent cations to the shocking fluid. Increasing concentrations of $\mathrm{CaCl}_{2}$ steadily reduced the amount of EntE, $F$ and $B / G$ in shockates, such that at $0.5 \mathrm{mM} \mathrm{CaCl}_{2}$ almost all EntF and EntE were retained in

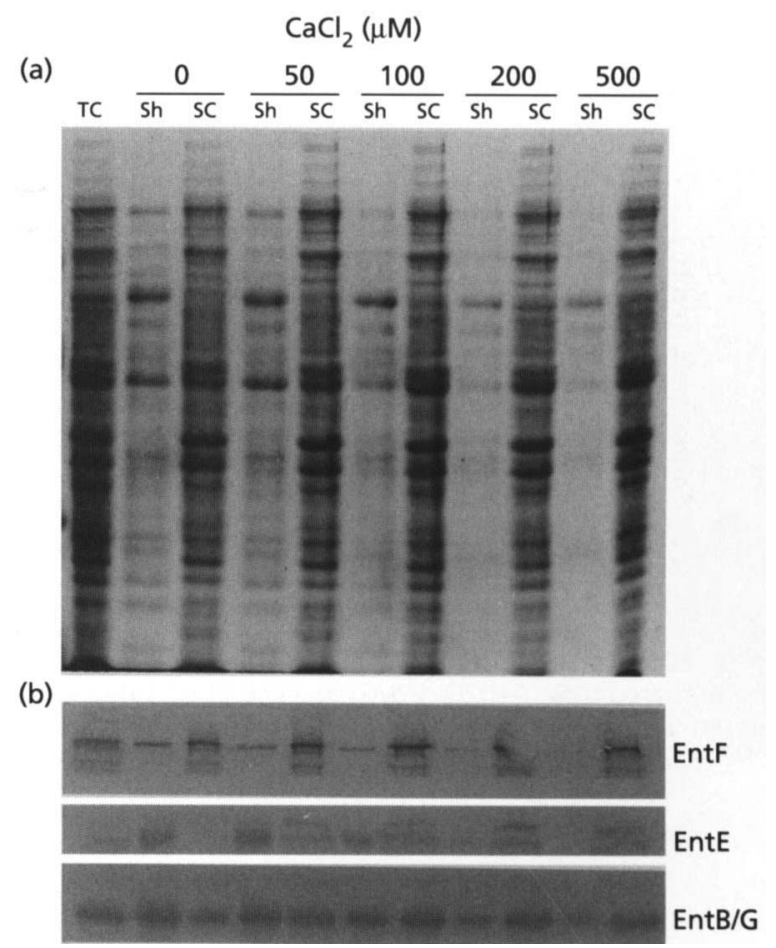

Fig. 4. Calcium suppression of osmotic shock release of Ent synthase components. AB1515 cells grown in TMM were plasmolysed in SET, harvested, and resuspended in $\mathrm{CaCl}_{2}$ solutions of concentrations $(\mu \mathrm{M})$ indicated at the top of (a). Proteins in shockates (Sh), shocked cells (SC), and total cells (TC) were resolved by electrophoresis in $11 \%$ polyacrylamide gels. (a) Coomassie Brilliant Blue-stained gel. (b) Western blot analyses of Ent synthase polypeptides present in shockates and shocked cells.

the shocked cells, as was most of EntB/G (Fig. 4). Similar results were observed when $\mathrm{MgCl}_{2}$ was used in place of $\mathrm{CaCl}_{2}$. These results differ from previous data of others in that this diminution of proteins released from the shockate fraction was not specific to group D proteins.

\section{Osmotic shock of Ent synthase mutants}

If Ent synthase proteins exist in a complex, a defective or absent unit of the complex could alter its intracellular location and thereby influence the osmotic shock retention of other components. To test this possibility, strains with mutations in each of the Ent synthase components were subjected to the shock procedure (Fig. 5). AB1515.43 has a Tn5 insertion in the $3^{\prime}$ end of ent $B / G$; the truncated protein can be detected and is $\mathrm{EntB}^{+} \mathrm{G}^{-}$. That is, it is still an active isochorismatepyruvate hydrolase but cannot carry out the EntG reaction. In contrast, AB1515.24 is defective in both reactions; the $\operatorname{Tn} 5$ insertion is in the $5^{\prime}$ end of ent $B / G$ and no product can be observed. In both mutants, EntE and EntF were released normally. Similarly, point mutations in entE (AN93) and entF (AN117) did not 
eliminate the shockability of their cognate proteins or that of other Ent synthase components. Lastly, AB1515.5-4 (Tn5::entD) likewise had no effect on retention of other Ent synthase components, a finding of interest since EntD has been proposed to anchor the putative complex to membrane. In summary, the shockability of other Ent synthase polypeptides was independent of EntB/G and EntD; evidence with respect to EntE and EntF was similar but less rigorous because of the nature of the mutation involved.

\section{Ent synthase activity of shocked cells and shockates}

The Ent synthase activity in extracts prepared from shocked AB1515 and W3110 cells was approximately $63 \%$ of that of normal extracts. The corresponding shockates did not have significant Ent synthase activity.

\section{DISCUSSION}

The primary finding of this work is that several Ent synthase components meet the definition of group D proteins, i.e. they are cytoplasmic proteins found in cell supernatants following osmotic shock but not after spheroplasting (Beacham, 1979). Western blot analyses disclosed that most of the EntE and EntB/G proteins are released by osmotic shock treatment. Shockates contained lesser, variable amounts of EntF, which may be related to the fact that EntF is an unusually large $(142 \mathrm{kDa})$ polypeptide. Cytoplasmic proteins DnaA, $\beta$ galactosidase, DNA polymerase III subunits $\tau$ and $\gamma$, and ACP were not released by shock, showing that the presence of Ent proteins in shockates was not the result of cell breakage. The results with the small $(8.86 \mathrm{kDa})$ ACP molecules confirm previous findings of Van den Bosch et al. (1970).

Nine group D proteins, most of which are enzymes concerned with nucleoside catabolism, were initially identified by Beacham (1979). Since that time, thioredoxin (Lunn \& Pigiet, 1982) and DnaK (El Yaagoubi et al., 1994) have been so categorized. The three Ent proteins thus bring the total of E. coli group D proteins to 14 but it is likely that many more exist. The present work suggests that biosynthetic enzymes for other siderophores, particularly those that involve nonribosomal synthesis of peptide bonds, may be group D proteins. In fact, evidence of Viswanatha et al. (1987) indicates that aerobactin synthase has an unusual intracellular location. More generally, because EntE and EntF and now EntB/G share homologies with proteins involved in thio-template-directed peptide synthesis, it is possible that many proteins concerned with the biosynthesis of surfactants and peptide antibiotics may be members of the group D class.

Whether or not any EntA or EntC, two proteins required for early steps in Ent biosynthesis, are present in shockates has not yet been determined. No antibodies are available for either and assays for these enzymes are difficult (Walsh et al., 1990). However, results shown in Fig. 5 with AB1515.43 demonstrate that the EntB activity (isochorismate-pyruvate hydrolase, the catalyst that converts the product of EntC into the substrate for EntA) of EntB/G is shockable in the absence of EntG; the $\mathrm{N}$-terminus of the protein is sufficient for osmotic shock release. Definitive evidence regarding EntD in shockates is lacking. Shockates were devoid of Ent synthase activity and attempts to perform enzymic complementation with extracts from Ent synthase mutants supplemented with shockates from wild-type cells were similarly negative. Possibly components in addition to EntD, E, F and B/G may be necessary for Ent synthase activity (Bryce \& Brot, 1972); lack of these auxiliary factors could explain the absence of activity in shockates even if EntD were present. There is no ready explanation for the failure of shockates to provide the necessary activity to mutant extracts, since group D proteins in shockates have often been shown to be active (Jacobson \& Rosenbusch, 1976; Munch-Peterson \& Mygind, 1976; Page \& Burton, 1978).

Whether or not Ent synthase exists as a complex in vivo remains unknown. In vitro data showed (i) the enzyme was active in the presence of high concentrations of neutral detergents and (ii) immunoprecipitation experiments conducted under conditions where the enzyme would be active failed to provide any evidence for a complex. However, EntB/G, E and $F$ all share the unusual property of being a group $D$ protein, which suggests they might be in close proximity to one another in vivo. Additional indirect evidence possibly indicative of an in vivo complex is the low activity of extracts prepared by sonication and the absence of Ent synthase 
activity in shockates. The complex, if it exists, may be transitory. Furthermore, the apparent ability of EntE, $F$ and $B / G$ to reside in several cellular locations (i.e. the cytoplasm and a shock-sensitive region) raises the possibility that in vivo the enzyme may be active in only one of the two regions.

The osmotic shockability of group D proteins is generally attributed to their loose or partial association with the inner surface of the cytoplasmic membrane (Beacham, 1979); indeed, such a peripheral membrane association has been reported for EFTu (Jacobson \& Rosenbusch, 1976), DnaK (El Yaagoubi et al., 1994) and thioredoxin (Lunn \& Pigiet, 1982). Lunn \& Pigiet (1982) suggested, more specifically, that group $D$ proteins are located at zones of adhesion between inner and outer membrane and, for thioredoxin, have adduced evidence in support of this proposal (Bayer et al., 1987; Lunn \& Pigiet, 1986). Therefore, that EntE, $F$ and $B / G$ are group $D$ proteins is indirect evidence that some fraction of them is membrane-associated. In fact, in a preliminary report EntB/G was detected in cytoplasmic membrane fractions (Hantash \& Earhart, 1995) and more recently some EntE and EntF have been similarly localized (unpublished observations). This association was not required for in vitro Ent synthase activity, however, as the enzyme was active in high-speed supernatants and in detergent, conditions where membrane would be absent or disrupted, respectively. The relationship of the in vitro cytoplasmic activity to in vivo activity remains the major question.

One other type of polypeptide recently identified as being osmotically shockable may provide additional insight into the in vivo positioning of group $\mathrm{D}$ proteins. Periplasmic proteins synthesized with no signal sequences are group D proteins (Bowden et al., 1992; Derman et al., 1993). Evidence suggests that these altered proteins are present in the cytoplasmic membrane export machinery at the time of their release by shock. Possibly, then, identification of a protein as being in the group D class may indicate that not only is at least some portion of the protein loosely associated with membrane but that the membrane site is one at which transmembrane passage occurs. This is consistent with properties of several group D proteins in addition to signal sequence mutants and thioredoxin; Beacham (1979) has discussed the possible role of many group $\mathrm{D}$ proteins in nucleoside uptake as well as catabolism and DnaK has a role in protein transmembrane targeting and secretion (Wild et al., 1996). Applied to Ent synthase, this hypothesis would suggest that the latter stages of Ent synthesis occur in association with an unidentified inner membrane export apparatus. Unfortunately, nothing is known regarding how Ent leaves the cytoplasm, and the results shown in Fig. 5 eliminate EntD as providing the putative localizing function necessary for shockability.

Lastly, the data further emphasize the ability of certain cytoplasmic proteins to be compartmentalized or to exist in several cellular locations in prokaryotic cells. In addition to group D proteins, prominent examples of such odd and interesting proteins include FtsZ
(Lutkenhaus, 1993), SecA (Economou \& Wickner, 1994), and CheA and CheW (Maddock \& Shapiro, 1993).

\section{ACKNOWLEDGEMENTS}

We thank C. Rock for ACP antiserum and J. Tommassen for referring us to the paper by Derman et al. (1993). This work was supported by Public Health Service grant GM47885 from the National Institutes of Health.

\section{REFERENCES}

Ammerlaan, M. C. (1994). Studies on enterobactin synthetase. $\mathrm{PhD}$ thesis, The University of Texas at Austin.

Armstrong, S. K., Pettis, G. S., Forrester, L. J. \& Mclntosh, M. A. (1989). The Escherichia coli enterobactin biosynthesis gene, entD: nucleotide sequence and membrane localization of its protein product. Mol Microbiol 3, 757-766.

Arnow, L. E. (1937). Colorimetric determinations of the components of 3,4-dihydroxyphenylalanine-tyrosine mixtures. $J$ Biol Chem 118, 531-537.

Bayer, M. E., Bayer, M. H., Lunn, C. A. \& Pigiet, V. P. (1987). Association of thioredoxin with the inner membrane and adhesion sites in Escherichia coli. J Bacteriol 169, 2659-2666.

Beacham, I. R. (1979). Periplasmic enzymes in Gram-negative bacteria. Int J Biochem 10, 877-883.

Borchert, S., Stackelhaus, T. \& Marahiel, M. A. (1994). Induction of surfactin production in Bacillus subtilis by gsp, a gene located upstream of the gramicidin S operon in Bacillus brevis. J Bacteriol 176, 2458-2462.

Bowden, G. A., Baneyx, F. \& Georgiou, G. (1992). Abnormal fractionation of $\beta$-lactamase in Escherichia coli: evidence for an interaction with the inner membrane in the absence of a leader peptide. J Bacteriol 174, 3407-3410.

Bradford, M. M. (1976). A rapid and sensitive method for the quantitation of microgram quantities of protein utilizing the principle of protein-dye binding. Anal Biochem 72, 248-254.

Braun, V. (1985). The unusual features of the iron transport systems of Escherichia coli. Trends Biochem Sci 10, 75-78.

Bryce, G. F. \& Brot, N. (1972). Studies on the enzymatic synthesis of the cyclic trimer of 2,3-dihydroxy- $\mathrm{N}$-benzoyl-L-serine in Escherichia coli. Biochemistry 9, 1708-1715.

Chenault, S. S. \& Earhart, C. F. (1991). Organization of genes encoding membrane proteins of the Escherichia coli ferrienterobactin permease. Mol Microbiol 5, 1405-1413.

Coderre, P. E. \& Earhart, C. F. (1984). Characterization of a plasmid carrying the Escherichia coli K-12 entD, fepA, fes, and entF genes. FEMS Microbiol Lett 25, 111-116.

Coderre, P. E. \& Earhart, C. F. (1989). The entD gene of the Escherichia coli $\mathrm{K} 12$ enterobactin gene cluster. J Gen Microbiol 135, 3043-3055.

Cox, G. B., Gibson, F., Luke, R. K. J., Newton, N. A., O'Brien, I. G \& Rosenberg, H. (1970). Mutations affecting iron transport in Escherichia coli. J Bacteriol 104, 219-226.

Crosa, J. H. (1989). Genetics and molecular biology of siderophore-mediated iron transport in bacteria. Microbiol Rev 53, 517-530.

Derman, A. I., Puziss, J. W., Bassford, P. J., Jr \& Beckwith, J. (1993). A signal sequence is not required for protein export in prlA mutants of Escherichia coli. EMBO J 12, 879-888.

Earhart, C. F. (1987). Ferrienterobactin transport in Escherichia 
coli. In Iron Transport in Microbes, Plants and Animals, pp. 67-84. Edited by G. Winkelmann, D. van der Helm \& J. B. Neilands. Weinheim: VCH Verlagsgesellschaft.

Economou, A. \& Wickner, W. (1994). SecA promotes preprotein translocation by undergoing ATP-driven cycles of membrane insertion and deinsertion. Cell 78, 835-843.

Elkins, M. F. \& Earhart, C. F. (1988). An Escherichia coli enterobactin cluster gene with sequence homology to $\operatorname{trp} E$ and $p a b B$. FEMS Microbiol Lett 56, 35-40.

El Yaagoubi, A., Kohiyama, M. \& Richarme, G. (1994). Localization of DnaK (chaperone 70) from Escherichia coli in an osmotic-shock-sensitive compartment of the cytoplasm. $J$ Bacteriol 176, 7074-7078.

Greenwood, K. T. \& Luke, R. K. J. (1976). Studies on the enzymatic synthesis of enterochelin in Escherichia coli K-12. Four polypeptides involved in the conversion of 2,3-dihydroxybenzoate to enterochelin. Biochim Biophys Acta 454, 285-297.

Greenwood, K. T. \& Luke, R. K. J. (1980). Studies on the enzymatic synthesis of enterochelin in Escherichia coli K-12, Salmonella typhimurium and Klebsiella pneumoniae. Physical association of enterochelin synthetase components in vitro. Biochim Biophys Acta 614, 185-195.

Grossman, T. H., Tuckman, M., Ellestad, S. \& Osburne, M. S. (1993). Isolation and characterization of Bacillus subtilis genes involved in siderophore biosynthesis: relationship between $B$. subtilis $s f p^{0}$ and Escherichia coli entD genes. J Bacteriol 175, 6203-6211.

Guilvout, I., Mercereau-Puijalon, O., Bonnefoy, S., Pugsley, A. P. \& Carniel, E. (1993). High molecular weight protein 2 of Yersinia enterocolitica is homologous to AngR of Vibrio anguillarum and belongs to a family of proteins involved in nonribosomal peptide synthesis. J Bacteriol 175, 5488-5504.

Hantash, F. \& Earhart, C. F. (1995). Membrane association of the Escherichia coli enterobactin synthetase protein EntB. Abstr Annu Meet Am Soc Microbiol, K-32.

Jacobson, G. R. \& Rosenbusch, J.P. (1976). Abundance and membrane association of elongation factor Tu in E. coli. Nature 261, 23-26.

Kaback, H. R. (1971). Bacterial membranes. Methods Enzymol 22, 99-120.

Kleinkauf, H. \& von Dohren, H. (1990). Nonribosomal biosynthesis of peptide antibiotics. Eur J Biochem 192, 1-15.

Langman, L., Young, I. G., Frost, G. E., Rosenberg, H. \& Gibson F. (1972). Enterochelin system of iron transport in Escherichia coli: mutations affecting ferric-enterochelin esterase. J Bacteriol 112, 1142-1149.

LaVallie, E. R., DiBlasio, E. A., Kovacic, S., Grant, K. L., Schendel, P. F. \& McCoy, J. M. (1993). A thioredoxin gene fusion expression system that circumvents inclusion body formation in the Escherichia coli cytoplasm. Bio/Technology 11, 187-192.

Lugtenberg, B., Meijers, J., Peters, R., van der Hoek, P. \& van Alphen, L. (1975). Electrophoretic resolution of the major outer membrane protein of Escherichia coli into four bands. FEBS Lett $58,254-258$.

Lunn, C. A. \& Pigiet, V. P. (1982). Localization of thioredoxin from Escherichia coli in an osmotically sensitive compartment. $J$ Biol Chem 257, 11424-11430.

Lutkenhaus, J. (1993). FtsZ ring in bacterial cytokinesis. Mol Microbiol 9, 403-409.

McIntosh, M. A. \& Earhart, C. F. (1977). Coordinate regulation by iron of the synthesis of phenolate compounds and three outer membrane proteins in Escherichia coli. J Bacteriol 131, 331-339.
Maddock, J. R. \& Shapiro, L. (1993). Polar location of the chemoreceptor complex in the Escherichia coli cell. Science 259, 1717-1723.

Marahiel, M. A. (1992). Multidomain enzymes involved in peptide synthesis. FEBS Lett 307, 40-43.

Miller, J. H. (1972). Experiments in Molecular Genetics. Cold Spring Harbor, NY: Cold Spring Harbor Laboratory.

Munch-Petersen, A. \& Mygind, B. (1976). Nucleoside transport systems in Escherichia coli K12: specificity and regulation. J Cell Physiol 89, 551-560.

Neilands, J. B. (1981a). Microbial iron compounds. Annu Rev Biochem 50, 715-731.

Neilands, J. B. (1981b). Microbial iron transport compounds (siderophores) as chelating agents. In Development of Iron Chelators for Clinical Use, pp. 13-31. Edited by A. E. Martell, W. F. Anderson \& D. G. Badman. Amsterdam : Elsevier.

Nossal, N. G. \& Heppel, L. A. (1966). The release of enzymes by osmotic shock from Escherichia coli in exponential phase. $J$ Biol Chem 241, 3055-3062.

Page, M. G. P. \& Burton, K. (1978). The localization of purine phosphoribosyltransferase activities in Escherichia coli. Biochem $J$ 174, 717-725.

Pierce, J. R. \& Earhart, C. F. (1986). Escherichia coli K-12 envelope proteins specifically required for ferrienterobactin uptake. $J$ Bacteriol 166, 930-936.

Pierce, J. R., Pickett, C. L. \& Earhart, C. F. (1983). Two fep genes are required for ferrienterobactin uptake in Escherichia coli K-12. J Bacteriol 155, 330-336.

Reichert, J., Sakaitani, M. \& Walsh, C. T. (1992). Characterization of EntF as a serine-activating enzyme. Protein Sci 1, 549-556.

Rusnak, F., Faraci, W. S. \& Walsh, C. T. (1989). Subcloning, expression, and purification of the enterobactin biosynthetic enzyme 2,3-dihydroxybenzoate-AMP ligase: demonstration of enzyme-bound (2,3-dihydroxybenzoyl)adenylate product. Biochemistry 28, 6827-6835.

Rusnak, F., Liu J., Quinn, N., Berchtold, G. A. \& Walsh, C. T. (1990). Subcloning of the enterobactin biosynthetic gene entB: expression, purification, characterization, and substrate specificity of isochorismatase. Biochemistry 29, 1425-1435.

Rusnak, F., Sakaitani, M., Drueckhammer, D., Reichert, J. \& Walsh, C. T. (1991). Biosynthesis of the Escherichia coli siderophore enterobactin: sequence of the entF gene, expression and purification of EntF, and analysis of covalent phosphopantetheine. Biochemistry 30, 2916-2927.

Sambrook, J., Fritsch, E. F. \& Maniatis, T. (1989). Molecular Cloning : a Laboratory Manual, 2nd edn. Cold Spring Harbor, NY: Cold Spring Harbor Laboratory.

Schlumbohm, W., Stein, T., Ullrich, C., Vater, J., Krause, M., Marahiel, M. A., Kruft, V. \& Wittman-Liebold, B. (1991). An active serine is involved in covalent substrate amino acid binding at each reaction center of gramicidin S synthetase. J Biol Chem 266, 23135-23141.

Silver, S. \& Walderhaug, M. (1992). Gene regulation of plasmidand chromosome-mediated inorganic ion transport in bacteria. Microbiol Rev 56, 195-228.

Staab, J. F. \& Earhart, C. F. (1990). EntG activity of Escherichia coli enterobactin synthetase. J Bacteriol 172, 6403-6410.

Studier, F. W., Rosenberg, A. H., Dunn, J. J. \& Dubendorff, J. W. (1990). Use of T7 RNA polymerase to direct expression of cloned genes. Methods Enzymol 185, 60-89.

Turgay, K., Krause, M. \& Marahiel, M. A. (1992). Four homologous 
domains in the primary structure of GrsB are related to domains in a superfamily of adenylate-forming enzymes. Mol Microbiol 6, 529-546.

Van den Bosch, M., Williamson, J. R. \& Vagelos, P. R. (1970). Localization of acyl carrier protein in Escherichia coli. Nature 228, 338-341.

Viswanatha, T., Szezepan, E. W. \& Murray, G. J. (1987). Biosynthesis of aerobactin: enzymological and mechanistic studies. In Iron Transport in Microbes, Plants and Animals, pp. 117-132. Edited by G. Winkelmann, D. van der Helm \& J. B. Neilands. Weinheim: VCH Verlagsgesellschaft.

Walsh, C. T., Liu, J., Rusnak, F. \& Sakaitani, M. (1990). Molecular studies on enzymes in chorismate metabolism and the enterobactin biosynthetic pathway. Chem Rev 90, 1105-1129.
Wild, J., Rossmeissl, P., Walter, W. A. \& Gross, C. A. (1996). Involvement of the DnaK-Dna J-GrpE chaperone team in protein secretion in Escherichia coli. J Bacteriol 178, 3608-3613.

Woodrow, G. C., Young, I. G. \& Gibson F. (1975). Mu-induced polarity in the Escherichia coli K-12 ent gene cluster : evidence for a gene (ent $G$ ) involved in the biosynthesis of enterochelin. $J$ Bacteriol 124, 1-6.

Woodrow, G. C., Young, I. G. \& Gibson, F. (1979). Biosynthesis of enterochelin in Escherichia coli K-12. Separation of the polypeptides coded for by the entD, E, $F$ and $G$ genes. Biochim Biophys Acta 582, 145-153.

Received 12 April 1996; revised 30 July 1996; accepted 19 August 1996. 